\title{
Pers Mengawal Demokrasi Daerah: Analisis Pemberitaan Implementasi Dana Keistimewaan di Harian Tribun Jogja
}

\author{
Niti Bayu Indrakrista.
}

\begin{abstract}
This paper examines the role of local press as institution that supports democracy in regional level, in decentralisation era. As an entry point, this paper uses the media coverage of Dana Keistimewaan in Tribun Jogja daily newspaper, a non-partisan press institution that established at post New Order era. Using Robert Entman's framing analysis, this research argues that consolidation of democracy has not yet fully embedded at regional level. Local press pays too many attention on technocratic administrative aspects, rather than democratic ones that may involve contribution of the people.
\end{abstract}

\section{Keywords:}

democracy; local media; public watchdog; policy implementation; embedded democracy.

\begin{abstract}
Abstrak
Tulisan ini melihat mengenai peran pers lokal sebagai pilar pendukung demokrasi daerah pada era desentralisasi. Pintu masuk yang digunakan adalah pemberitaan implementasi Danais di Harian Tribun Jogja, sebuah lembaga pers non partisan yang berdiri pasca Orde Baru. Menggunakan perangkat analisis framing Robert Entman, terlihat bahwa konsolidasi demokrasi belum cukup mengakar di daerah. Pers lokal masih terlalu menitikberatkan perhatian pada aspek teknokratis administratif, dan kurang memperhatikan aspek demokratis yang melibatkan peran serta masyarakat.
\end{abstract}

\section{Kata kunci:}

demokrasi; media lokal; public watchdog; implementasi kebijakan; demokrasi mengakar.

\section{Pendahuluan}

Gelombang demokratisasi di Indonesia pasca runtuhnya OrdeBaru menjalar keberbagai aspek. Dalam hubungan antara pemerintahan pusat dan daerah, salah satu perubahan yang paling mencolok yaitu menguatnya pembagian kewenangan pemerintah dari pusat ke tingkat daerah, atau yang biasa disebut desentralisasi. Dari segi regulasi dan pembagian kapling kewenangan pemerintahan pusat-daerah, isu ini telah menjadi perdebatan sejak digulirkannya. Aspek yang masih kurang mendapat perhatian adalah bagaimana demokrasi dapat turut terdistribusi ke daerah, seiring meluasnya kewenangan dan kekuatan pemerintahan level sub nasional.

Meski terkesan sangat dekat dan berimpitan, hubungan antara konsep demokrasi

\footnotetext{
- Mahasiswa Pascasarjana Jurusan Politik dan Pemerintahan FISIPOL UGM, Yogyakarta.
} Email: bayuindrakrista@gmail.com 
dengan desentralisasi terus menjadi perdebatan. Apakah yang satu menjadi penyebab lainnya? Apakah kemunculan salah satu konsep merupakan gejala dari hidupnya konsep satunya? Nordholt dan van Klinken (2007) misalnya, menyebut bahwa desentralisasi tidak bisa disamakan dengan demokratisasi. Mereka bersandar pada bukti hadirnya desentralisasi di sejumlah negara otoriter. Di sisi lain, ada argumen yang menguatkan posisi desentralisasi sebagai konsep yang linier dengan demokrasi. Terdapat sejumlah dampak dari desentralisasi (dari kacamata ideal) yang bisa membuat pemerintahan di daerah menjadi lebih efektif dalam mendistribusikan sumber daya, lebih responsif terhadap aspirasi masyarakat lokal, menguatkan akuntabilitas, serta mewujudkan good governance (Sharma, 2004). Kelompok ini menyebut bahwa pemerintah lokal seharusnya lebih dipercaya untuk memenuhi kebutuhan warga karena mereka dinilai lebih memiliki informasi tersebut (Tsai, 2007). Tujuan diserahkannya sejumlah kewenangan pemerintahan ke daerah yaitu sebagai pelaksanaan demokrasi sejak tahap grass root (Mariun dalam Kaho, 2012).

Dalam kerangka mewujudkan pemerintahan yang baik dan demokratis, peran institusi penjaga yang berdiri di luar struktur formal pemerintahan menjadi penting. Pers menjadi lembaga pengemban tanggung jawab tersebut. Secara ideal, pers memiliki kesetiaan pada kepentingan masyarakat serta kewajiban untuk menyuarakan kebenaran (Ishwara, 2008). Pertanyaan yang lantas bisa diajukan adalah, sejauh mana pemerintah daerah siap berinteraksi dengan keberadaan pers. Dengan kewajiban yang semakin besar, penulis menilai pemerintah daerah perlu mendapat pengawasan yang lebih kuat dari media massa setempat, serta bersedia mempertimbangkan pesan yang disampaikan melalui cetakannya. Aspek tersebut menjadi penting demi menghindari pemerintahan yang berjalan semaunya sendiri, sehingga penyebaran demokrasi hingga tingkat bawah bisa terwujud secara nyata. Apalagi pemerintah dipercaya untuk mengelola uang negara, yang bagaimanapun terkumpul dari sumbangan masyarakat dalam bentuk pajak.

Lantas bagaimana dengan konteks Indonesia? Sebagai negara kesatuan (bukan federal), terdapat dua pilihan yang bisa diambil oleh bangsa ini dalam konteks tersebut, yaitu menjadi negara dengan sistem yang tersentralisasi, atau mengaplikasikan gaya desentralisasi. Josef Riwu Kaho (2012) menjelaskan bagaimana sejak jaman kolonial, bangsa yang mendiami wilayah Nusantara ini mengalami tarik ulur antara kedua kutub itu. Pada bidang apa saja yang menjadi wewenang pemerintahan setiap tingkat, menjadi wacana yang bergulir dan selalu menuai kritik serta mengalami perbaikan. Termasuk pada era reformasi, ketika regulasi terkait kewenangan pemerintah daerah (baik provinsi maupun kabupaten/kota) merupakan bentuk perbaikan dari regulasi sebelumnya, sehingga pengaturan mengenai detail-detail kewenangan tersebut menjadi semakin jelas.

Terkait upaya konsolidasi demokrasi pada tingkat pemerintahan daerah yang terjadi pasca reformasi 1998, tulisan ini akan mengangkat mengenai bagaimana media di Indonesia sebagai salah satu pilar demokrasi memahami peran barunya. Ruang penelitian di Daerah Istimewa Yogyakarta, di mana kasus yang diangkat sebagai entry point adalah pemberitaan implementasi Dana Keistimewaan DIY oleh Harian Tribun Jogja.

Dana Keistimewaan (Danais) merupakan sebuah kebijakan yang lahir relatif baru, sebagai konsekuensi ditetapkannya UU Keistimewaan DIY oleh pusat. Kebijakan ini juga menarik karena kaitannya dengan demokrasi, yaitu singgungan Danais dengan kekuatan tradisional di DIY yang berbentuk kesultanan, namun secara riil bekerja di dalam sistem demokrasi. Kekuatan yang dimaksud adalah Keraton Yogyakarta, yang 
kini mendapat peran barunya dalam struktur formal kepengurusan pemerintah DIY. Jika dikelola secara keliru, Danais berpotensi memperkuat keganasan kalangan tertentu dalam masyarakat yang mempunyai privilege tertentu seperti yang dikhawatirkan oleh sejumlah LSM. ${ }^{1}$ Perlu diperhatikan, tulisan ini tidak akan membahas secara khusus mengenai UU Keistimewaan itu sendiri, ataupun posisi para bangsawan Keraton di kepengurusan Pemda DIY. Pembahasan akan fokus pada isu yang diangkat dalam media lokal mengenai implementasi Danais yang merupakan simbol dari titik temu antara kekuatan-kekuatan demokratis dengan primordial pada tingkat daerah.

Adapun Tribun Jogja dipilih karena posisinya sebagai media lokal non partisan yang terbit di Yogyakarta pada era reformasi. Tribun Jogja merupakan bagian unit koran daerah yang dimiliki konglomerasi Kompas Gramedia. Berbeda dengan Surat Kabar harian (SKH) Kompas yang merupakan unit koran nasional milik Kompas Gramedia, Tribun Jogja (dan cabang Tribun di berbagai daerah lain) tidak terikat pada kebijakan redaksional seharihari dari pusat. Penentuan headline halaman pertama, misalnya, sepenuhnya berada di bawah wewenang pemimpin redaksi Tribun Jogja yang berkantor di Yogyakarta. Jadi bisa dikatakan, meskipun memiliki keterkaitan perusahaan, namun redaksi Tribun Jogja sama sekali terlepas dari pengaruh koran nasional SKH Kompas.

Analisis dilakukan menggunakan perangkat analisis framing Robert N. Entman (1993) untuk membaca sikap media terhadap isu tertentu melalui teks pemberitaannya. Dibanding perangkat analisis framing lain, seperti Gamson

${ }^{1}$ Contohnya ada dalam berita Tribun Jogja edisi Jumat, 13 Desember 2013 berjudul "Danais Bisa Jadi Bumerang" dengan sub judul "IDEA Sebut Pemda DIY Belum Siap Kelola Danais" ataupun pada edisi Kamis, 1 Mei 2014 berjudul "Djoko Siap Kawal Keistimewaan” dengan sub judul “Cegah Danais untuk Kelompok Gadungan yang memiliki total delapan framing devices dan Pan-Kosicki dengan sembilan framing devices, perangkat Entman lebih sederhana karena hanya memiliki empat framing devices. Sementara perangkat Edelman, yang jumlah perangkatnya lebih sedikit, mengkonstruksi teks dalam kategorisasi yang kemudian diperlawankan, sehingga kurang sesuai untuk konteks penelitian ini yang tidak memetakan aktor atau isu yang saling berhadapan (Eriyanto, 2002). Di sisi lain, unit-unit analisis yang disediakan Entman memadai dan sesuai untuk keperluan tulisan ini. Unit problem definition melihat apa yang dilakukan aktor dalam berita lengkap dengan cost and benefit yang akan didapat. Unit diagnose cause berisi identifikaisi pihak penyebab permasalahan. Unit moral judgement berisi evaluasi terhadap perilaku aktor dan dampaknya. Sementara suggest remedies menunjukkan penawaran solusi terhadap masalah yang disebutkan dalam teks (Entman, 1993).

\section{Demokrasi yang Mengakar}

Ide mengenai prasyarat minimal demokrasi, yaitu proses elektoral, telah mendapat cukup banyak koreksi dari para ahli (Beetham, 1999; Merkel, 2004; Lele, 2012). Mekanisme elektoral dianggap tidak lagi cukup menjadi jaminan dipraktikkannya demokrasi dalam masyarakat. Tahapan tersebut memang dianggap menjadi cerminan kedaulatan rakyat, bagaimana rakyat bisa mengontrol pemerintahan, menjatuhkan penilaian dan penghakiman terhadap kinerja para wakilnya. Namun mekanisme kontrol tersebut diyakini tidak bisa berlangsung secara berkesinambungan mengingat hanya bisa diadakan satu kali setiap beberapa tahun. Perlu ada variabel lain yang bisa mengindikasikan secara lebih baik aspek demokrasi yang terinstalasi pada sebuah bangsa.

Wolfgang Merkel (2004) menjelaskan demokrasi secara lebih utuh lewat konsep embedded democracy. Selain prosesi elektoral melalui pemilu, demokrasi mensyaratkan 
adanyajaminan bahwa secara prinsip demokrasi itu sendiri dipraktikkan dalam kehidupan sehari-hari. Kemudian, pemerintahan yang terpilih bisa menjalankan pemerintahannya secara riil dan efektif. Terdapat lima rezim dalam demokrasi yang bisa menjadi indikator. Pertama, rezim elektoral yang berbicara mengenai tahapan pemilu yang menjadi prasyarat dalam penentuan pemimpin, yang harus dilaksanakan secara terbuka, jujur, dan adil. Kedua, hak politik, sebuah prasyarat yang menuntut adanya ruang publik yang fair selain pemilu. Pers dan kebebasan berpendapat menjadi aspek di dalamnya. Ketiga, hak sipil yang menekankan pada praktek rule of law. Rezim keempat adalah pembagian kekuasaan dan akuntabilitas horizontal, yaitu pengawasan antar lembaga pemerintahan. Kelima, kekuatan efektif untuk memerintah yang berada di pihak yang telah dinyatakan sah untuk menguasai lewat mekanisme pemilu tadi. Simpul komponen-komponen tersebut juga dilingkupi sejumlah variabel eksternal yaitu konteks sosio ekonomi, civil society, serta situasi internasional dan regional.

Tulisan ini akan mengelaborasi performa pers dalam mendukung demokrasi. Konteksnya menyempit pada lokus pemerintahan daerah di Indonesia pasca Orde Baru. Media massa dilihat sebagai satu komponen yang memegang peran penting dalam konsolidasi demokrasi seiring distribusi kekuasaan yang semakin dipertegas. Dalam penjelasan embedded democracy di atas, pers berada di posisi untuk menyiapkan prasyarat hak politik. Pers menjadi mekanisme bagi masyarakat untuk mengontrol dan memberikan reward-punishment bagi pemerintahnya secara simultan dan berlangsung daily basis, bukan lagi terbatas setiap lima tahun sekali. Kontes pertarungan kepentingan bisa berlangsung setiap saat. Pers memungkinkan dibentuknya ruang publik yang bisa menjadi saluran penyampaian aspirasi dalam kerangka informal dan memicu sensitifitas institusi negara terhadap kepentingan dan preferensi masyarakatnya. Bersama rezim elektoral, hak sipil memungkinkan kontrol terhadap pemerintah; satu lewat proses pemilu, lainnya menggunakan cara yang lain yang lebih halus namun berlangsung terus menerus.

Distribusi ke pemerintahan level daerah berarti harus disertai kesiapan instrumeninstrumen pendukung demokrasi pula. Dengan logika tersebut, jalannya pemerintahan di daerah dalam pola desentralisasi harus pula mendapat pengawasan dari media yang berbasis pada daerah yang bersangkutan. Dengan demikian, demokrasi di daerah juga berdiri di atas empat pilar. Sesuai tujuan pers membuka ruang publik dan pengawasan untuk mendorong akuntabilitas, maka kehadiran pers lokal yang sehat dapat memaksa pemerintah lokal menerapkan good governance sebaik mungkin (Siregar, 2011). Perlu dicatat, asas desentralisasi tidak serta merta menjamin pemerintah di daerah siap dengan segala konsekuensi untuk mewujudkan demokrasi. Proses tersebut harus terus menerus dikawal, apalagi dalam situasi Indonesia di mana selama puluhan tahun pemerintah daerah terbiasa dengan gaya top-down dan gemar menanti instruksi pusat (Lele, 2012)

\section{Desentralisasi}

Prinsip desentralisasi lahir dari ide bahwa semua orang yang kepentingannya dipengaruhi oleh sebuah keputusan seharusnya dapat berpartisipasi pula dalam proses pembuatannya. ${ }^{2}$ Sudut pandang tersebut membuat gaya pemerintahan yang

\footnotetext{
2 Menurut Warioba (Maasoi dan Norman, 2009), terdapat dua jenis desentralisasi. Desentralisasi administratif yang biasa disebut dekonsentrasi, yaitu pendelegasian kekuasaan dari pusat ke unit lapangan departemen yang bersangkutan dan memberikan kewenangan membuat keputusan pada petugas di tingkat daerah. Sementara desentralisasi politis alias devolution, yaitu transfer kuasa pembuatan keputusan pada otoritas atau perwakilan lokal. Dalam prinsip ini, otoritas lokal bisa membuat hukum dan kebijakan dengan mempertimbangkan konteks di daerahnya.
} 
tersentralisasi semakin tidak mendapat tempat dalam tatanan yang demokratis tersebut (Aziz dan Arnold, 2003). Pola pikir tersebut semakin mendapat tempat pada era modern, bahkan bisa dibilang telah menjadi tren di berbagai penjuru dunia. Meski masingmasing negara memiliki pengertian dan implementasinya sendiri-sendiri untuk setiap periode waktu, namun sulit dipungkiri bahwa desentralisasi merupakan kebijakan yang digemari dan menjadi prioritas para pengambil kebijakan di berbagai negara (Sharma, 2004). Lebih mendasar, desentralisasi merupakan upaya memperlebar hak warga negara untuk berpendapat dan bersuara serta meminimalisasi kesenjangan hak-hak politik warga negara (Imawan, 2005). Uraian yang disebut terakhir menekankan betul bagaimana desentralisasi bermain pada ranah yang filosofis, sebelum terjun pada pengejawantahannya di level yang lebih konkret.

Terdapat sejumlah pendapat yang menyatakan bahwa secara ideal, desentralisasi memang menjadi solusi atau jalan tengah dari permasalahan yang dihadapi banyak negara. Misalnya, demi menghadapi konflik perbedaan etnis, pemerintah pusat di sejumlah negara rela memberikan kesempatan bagi daerah tertentu untuk mendapatkan otonomi dan ruang gerak yang lebih leluasa. Otonomi daerah juga kerap menjadi modus bagi negara untuk menghindari upaya separatis dari daerahnya yang memiliki kekayaan sumber daya yang begitu melimpah, dibandingkan daerah lain dalam negara yang bersangkutan. Penguatan struktur pemerintah sub nasional juga diimplementasikan untuk keperluan pembangunan kembali pasca konflik kekerasan, misalnya perang saudara ataupun invasi dari negara lain (Devas, 2005).

Kelebihan-kelebihan tersebut menunjukkan bahwa desentralisasi bisa saja menjadi pilihan yang diambil para pembuat kebijakan tanpa mempertimbangkan aspek demokratisasi sekalipun. Demi mengejar stabilitas di daerah misalnya, pemerintah pusat mengambil jalan desentralisasi demi menenangkan gelombang perlawanan. Jadi, demokratisasi tidak harus menjadi landasan desentralisasi, tidak pula demokrasi menjadi ujungnya. Penelitian Lily L. Tsai (2007) di kawasan pedesaan China, misalnya, menunjukkan bahwa performa pemerintah lokal yang akuntabel tidak harus beriringan dengan kualitas demokrasi di wilayah yang bersangkutan. Baik pengawasan dari struktur politik pusat maupun mekanisme pemerintahan yang demokratis, menurut Tsai, tidak serta merta menjamin adanya pemerintahan sub nasional yang mampu menyediakan pelayanan publik secara optimal.

\section{Desentralisasi Indonesia "Modern": Buah Reformasi}

Kebijakan desentralisasi di Indonesia seperti bentuknya yang saat ini tidak bisa dilepaskan kehadirannya dari gelombang reformasi yang melepaskan pemerintah pusat dari kepemimpinan otoriter dan sentralistik Soeharto. Baswedan (2007) menyebut, dari segi ide, desentralisasi di Indonesia pasca 1998 memang digagas dalam kerangka berpikir demokratisasi. Gaya politik sentralistis mendapat tantangan demokratisasi, yang diwujudkan dalam pemerintahan subnasional lewat desentralisasi dan otonomi daerah. Desentralisasi merupakan wujud buah yang nyata dari proses demokratisasi di Indonesia pasca runtuhnya Orde Baru (Haryanto, 2009)

Jika ditarik mundur jauh ke belakang, desentralisasi telah menjadi isu yang terus diperdebatkan bahkan sebelum bangsa ini menemukan bentuknya sebagai Indonesia. Pemerintahan kolonial Hindia Belanda melakukan upaya desentralisasi misalnya melalui pembagian negara dalam beberapa tingkat administratif. Begitu pula saat penjajahan Jepang, di mana pembagian dilakukan berdasarkan keperluan sebagai peserta Perang Dunia 2 yang saat itu masih panas berkecamuk. Setelah proklamasi 17 Agustus 
1945, desentralisasi masih menjadi prinsip yang diimplementasikan sebagai konsekuensi demokrasi, sebagaimana dikatakan salah satu proklamator Mohammad Hatta (Maryanov, 2009).

Istilah demokrasi memang akrab di telinga bangsa ini bahkan sejak kelahirannya. Gaungnya semakin menguat belakangan, ketika banyak pihak menuding gerakan reformasi membawa politik Indonesia semakin liberal. Namun demokrasi di Indonesia kerap kali menjadi sebatas senjata propaganda belaka. Sangat mudah menemui istilah tersebut keluar dari mulut para elit meski kemudian diikuti oleh tindakan atau kebijakan yang justru merusak kaidah demokrasi itu sendiri. Euforia wacana demokrasi bukanlah hal yang asing dalam politik Indonesia, termasuk pada era reformasi (Mahatma, 2006).

Gerakan reformasi 1998 mengusung semangat kebebasan dan sedikit sentimen anti pemerintah pusat. Gelombang tersebut menuntut tata pemerintah yang lebih demokratis, desentralis, dan transparan (Nordholt dan Klinken, 2007). Sejumlah regulasi pun dilahirkan demi mengejawantahkan desentralisasi yang seoptimal mungkin demi mencapai kesejahteraan masyarakat. Wacana yang dominan pada domain ini adalah sejauh mana pemerintah pusat merelakan berbagai urusan dipercayakan ke daerah. Bidang-bidang administratif mana yang menjadi wewenang daerah, serta bagaimana daerah mengelola keuangannya sendiri. Sementara diskusi pada tahap yang lebih filosofis-demokratis masih kurang begitu dilirik.

Sejumlah peneliti (Lay, 2012; Lele, 2012; Sugiharta, 2012) telah menjabarkan bagaimana prinsip tersebut berjalan di Indonesia selama kurang lebih satu dekade setelah runtuhnya Orde Baru. Secara umum, sejumlah ilmuwan menilai pelaksanaan desentralisasi di Indonesia masih memerlukan pengawasan. Pasalnya, secara riil, praktik pemerintahan sehari-hari malah semakin menjauh dari prinsip dan tujuan demokrasi yang ingin dituju. Lay (2012) menjelaskan, perjalanan desentralisasi di Indonesia selama kurang lebih satu dekade hanya menjadi ajang konsolidasi kekuatan politik lama yang menimbulkan fenomena pembajakan demokrasi, atau malah diisi oleh orang-orang baru yang mempraktikkan praktik politik kotor yang kerap digunakan pada rezim sebelumnya yang bergaya otoriter. Sugiharta (2012) memandang permasalahan desentralisasi terutama dalam konteks pelestarian cagar budaya bisa diselesaikan melalui reformasi aparatur pemerintahan di daerah secara sistematis. Sementara Lele (2012) menggunakan sebutan paradox jarak untuk menggambarkan bagaimana desentralisasi malah menjauhkan rakyat daerah dari pemerintahan lokal, yang secara geografis jaraknya lebih dekat dengan mereka dibanding pemerintah pusat.

\section{Pers Lokal}

Penulis menilai perlu menggarisbawahi pentingnya peran institusi di luar pemerintahan untuk menjaga gelombang perubahan tersebut. Dalam hal ini, ada sebuah institusi yang sejak awal memang dirancang untuk menjalankan fungsi tersebut, serta telah lama mengambil posisi (baik dalam pengertian geografis maupun sosiologis) yang tepat, yaitu media massa atau pers lokal. Media dipercaya menjagi bel peringatan yang siap meneriakkan pelanggaran yang mungkin dilakukan oleh penguasa, layaknya anjing penjaga yang mengendus datangnya pencuri di malam hari. Pers disebut memegang tugas untuk mencegah agar jangan sampai ada bagian manapun dari pemerintah yang menipu masyarakat (Schechter, 2007; Ishwara, 2008). Secara konsisten, maka urutan premisnya menjadi demikian: demokratisasi di Indonesia diwujudkan (salah satunya) dalam bentuk desentralisasi, yang berarti demokratisasi juga menjalar sampai ke daerah di mana peran pers pada tingkat lokal bisa sesignifikan rekanrekan mereka di pusat. 
Pasca jatuhnya Orde Baru, dunia pers Indonesia mendapatkan kebebasan yang telah lama diidamkan, hasil disahkannya UU No. 40 tahun 1999 tentang Pers. Jaminan terhadap kebebasan pers digulirkan oleh pemerintah, sementara momok Surat Izin Usaha Penerbitan Pers (SIUPP) yang sebelumnya menjadi kartu truf pemerintah untuk membredel media yang dianggap mbeling, telah dihapuskan. Menurut data yang dimiliki Dewan Pers, sampai pada Februari 2011 terdapat setidaknya 952 terbitan media cetak di Indonesia, baik lokal maupun nasional. Jumlah media massa yang beredar di Jakarta sendiri masih terlalu dominan, yaitu mencapai angka 323, atau hampir 34 persen dari keseluruhan media massa yang beredar di Nusantara. Sisanya sebanyak 629 terbitan disebar di 32 provinsi lain (Sutrisno, 2011). Padahal secara ideal, kehadiran pers lokal dalam konteks otonomi daerah memegang peranan penting dalam mewujudkan good local governance. Sebagai wahana informasi di mana berbagai ide dan gagasan publik menemukan wadahnya, media mengambil fungsi sebagai wujud partisipasi masyarakat daerah yang keberadaannya mutlak diperlukan dalam pengambilan keputusan oleh pemerintah daerah (Yusuf, 2011).

Secara sekilas peran media massa, terutama pada tataran lokal, terasa tidak terlalu vital dalam jalannya roda pemerintahan sehari-hari. Namun, fungsi media yang bisa mengawasi jalannya pemerintahan sekaligus mengangkat atau mengarusutamakan aspirasi masyarakat. Akuntabilitas alias pertanggungjawaban serta transparansi yaitu terbukanya akses kepada semua stakeholders (Kumorotomo, 2005) bisa ditunjang oleh kehadiran institusi pers yang berintegritas, sensitif, dan kompeten. Analisis terhadap desentralisasi di Indonesia, serta peran pers di dalam menjaga proses demokratisasi di dalamnya, sama sekali bukan hal yang baru. Namun, peneliti memandang, banyak tulisan yang mengupas sisi medianya saja. Misalnya bagaimana profesionalitas media terombangambing di tengah tekanan pasar dan kekuatan politik (Yusuf, 2011; Sutrisno, 2011). Studi-studi tersebut menarik faktor-faktor yang biasa digunakan dalam menganalisis peran media massa pada umumnya (tingkat nasional), kemudian menggunakannya pada konteks pers lokal. Sementara perjalanan wacana yang telah dilemparkan ke publik, biasanya masuk pada bagian pendahuluan, bukan menjadi topik yang ikut dianalisis. Padahal, menurut pandangan penulis, fungsi media tidak bisa berhenti pada koreksi internal institusi mereka sendiri. Peran secara signifikan bisa diraih ketika apa yang mereka suarakan bisa memberi dampak nyata.

Di sisi lain, studi pada level pemerintahan (dan masyarakat) terkaitkebijakan desentralisasi cenderung melepaskan faktor keberadaan media massa. Misalnya mengenai tarik ulur hubungan antara pemerintah pusat dan daerah, regulasi dan pembagian kewenangan yang terus berubah, atau kegagalan lembaga intermediary menjalankan fungsi linkage (Kaho, 2012; Lay, 2012; Lele, 2012; Nordholt dan van Klinken, 2007). Sebagian dari tulisan-tulisan itu sudah menyinggung peran pers lokal, namun enggan menyelaminya. Padahal, representasi dan jarak imajiner antara rakyat dengan pemerintah lokal beberapa kali disebut sebagai faktor yang menentukan berhasil tidaknya proses desentralisasi di Indonesia (di mana kebanyakan peneliti masih memberikan rapor merah). Masalah tersebut, penulis menduga, berada pada domain yang sama dengan fungsi media massa.

\section{Framing Entman}

Analisis framing merupakan perangkat analisis yang jamak digunakan untuk membedah konstruksi pemberitaan dalam media massa, meski bisa pula digunakan untuk berbagai jenis tes lainnya. Berada dalam kerangka konstruksionisme, analisis framing meyakini bahwa berita merupakan hasil kontruksi, bentuk terjemahan atas 'realitas' yang terjadi di lapangan dan diamati oleh wartawan. Wartawan dalam hal ini tidak bisa 
sepenuhnya menjadi cermin atas apa yang terjadi di lapangan. Hasil pemberitaan telah lebih dulu mengalami seleksi. Fakta-fakta yang lolos seleksi akan dipilih kembali oleh media (baik itu wartawan maupun editor) untuk menentukan fakta mana yang ditonjolkan, dan mana yang ditepikan atau bahkan disingkirkan. Penonjolan berarti membuat informasi tertentu menjadi lebih berarti, noticable, atau mudah diingat oleh khalayak (Entman, 1993).

Dalam uraiannya, Entman menyebut ada empat poin yang harus disimak untuk membedah pembingkaian teks. Pertama, define problem yaitu apa yang dilakukan oleh aktor dalam berita serta keuntungan dan biaya apa yang harus ditanggung. Kemudian diagnose cause, yaitu identifikasi kekuatan apa yang menyebabkan permasalahan yang bersangkutan. Ketiga, moral judgements atau evaluasi mengenai perilaku agen dan dampaknya, yang ditampilkan dalam pemberitaan. Terakhir adalah suggest remedies yaitu penawaran solusi atas masalah, serta prediksi dampak dari tawaran tersebut jika diterapkan. Tidak semua teks berita memiliki keempat poin tersebut. Sebaliknya, akan jamak ditemui satu bagian teks yang sekaligus bisa melekat pada lebih dari satu fungsi framing di atas (Entman, 1993).

Menggunakan perangkat framing Entman yang telah diuraikan di atas, analisis akan dilakukan terhadap teks berita dalam Harian Tribun Jogja, sebuah unit produksi di bawah perusahaan Kompas Gramedia yang juga memiliki Harian Kompas, mengenai isu pemanfaatan Dana Keistimewaan (Danais) DIY periode pertama. Danais pertama kali dikucurkan pada tahun 2013 sebagai konsekuensi dari disahkannya UndangUndang Keistimewaan. Sejak awal proses kelahirannya, Danais sudah memancing kontroversi karena dianggap terburu-buru dan serba tidak siap (tempo.co, 1 Februari 2013). Pelaksanaan perdana itu pun mendapat sejumlah sorotan dan kritik dari media lokal, di antaranya terkait ketepatan alokasi dengan peraturan yang membatasinya, tingkat serapan yang minim, sejumlah program yang dianggap mengada-ada, sampai kekhawatiran rawannya alokasi dana itu dikutip secara ilegal dan tidak bertanggungjawab. Ada sebuah program, misalnya, berupa sosialisasi pencegahan penyakit malaria melalui pentas wayang. Cara tersebut dinilai dipaksakan demi masuk dalam ranah budaya sehingga bisa menggunakan Danais (tribunjogja.com, 16 Januari 2014). Dalam kerangka pikir tersebut, peneliti menilai perlu adanya penelitian yang secara khusus melihat sejauh mana fungsi pengawasan oleh pers lokal terhadap pemerintah daerah signifikan dalam perumusan kebijakan publik, sebagai mekanisme demokrasi yang idealnya ikut mengalir ke daerah sebagai akibat dari kebijakan desentralisasi. Kerangka waktu yang digunakan yaitu pertengahan tahun 2013 hingga pertengahan tahun 2014, di mana dari pers atas jalannya periode Danais pertama sudah berjalan, kemudian periode kedua akan dilaksanakan dan sudah berjalan pula termin awalnya.

\section{Keberpihakan Tak Kasat Mata}

Melalui proses observasi dilakukan terhadap pemberitaan di Harian Tribun Jogja mengenai implementasi Danais pada kurun waktu semester kedua 2013 hingga semester pertama $2014^{3}$, dapat dikategorikan lima kelompok sub-topik pemberitaan Danais. Kelima kategori tersebut yaitu:

\footnotetext{
${ }^{3}$ Periode waktu tersebut dipilih karena mencakup paruh kedua masa pencairan Danais periode pertama, persiapan Danais Periode kedua, hingga paruh awal Danais periode kedua. Dengan demikian, masalahmasalah perdana pelaksanaan Danais sudah terlihat. Begitu pula hasil evaluasi yang tercermin (dan tidak tercermin) pada penganggaran serta implementasi Danais periode berikutnya, sudah tampak. Setelah data dikumpulkan, dikelompokkan, dan dibaca menggunakan perangkat analisis framing, hasilnya akan dibenturkan dengan teori demokrasi dan dituangkan pada bagian kesimpulan.
} 
- Pembuatan dan pembagian rekening abdi dalem yang menerima honor dari Danais (5 Desember 2013, 6 Desember 2013, 14 Desember 2013, 28 Desember 2013, 29 Desember 2013, 25 April 2014, 13 Mei 2014, 14 Mei 2014);

- Urgensi pembuatan Perda Keistimewaan (Perdais) yang mengontrol batasan interpretasi kewenangan keistimewaan, serta rendahnya serapan Danais pada tiap terminnya (11 Desember 2013, 12 Desember 2013, 13 Desember 2013 [2berita], 6 Januari 2014, 29 April 2014 [2berita], 1 Mei 2014 [2berita], 23 Juni 2014 [2berita] 26 Juni 2014, 8 Agustus 2014);

- Ketepatan prioritas dan alokasi pemanfaatan Danais (26 Desember 2014, 27 Desember 2014, 1 April 2014, 5 April 2014 [2berita], 21 April 2014, 23 April 2014 [2berita], 25 Juni 2014 [2berita]);

- Polemik honor bagi Sri Sultan Hamengku Buwono $X$ dari Danais sebagai raja di Keraton Kesultanan Yogyakarta (4Desember 2013, 3 Januari 2014, 6 Januari 2014, 8 Januari 2014, 13 Februari 2014 [2berita]);

- Program yang janggal dan cenderung dipaksakan dengan tema kebudayaan yang bisa di-cover Danais, terutama program sosialisasi pencegahan penyakit malaria menggunakan media pentas wayang di Kabupaten Kulon Progo (11 Desember 2013, 12 Desember 2013, 13 Februari 2014)

Dari kelima sub-tema tersebut, analisis framing dilakukan terhadap empat sub-tema yang disebut belakangan. Sementara poin pertama, yaitu mengenai rekening abdi dalem, diabaikan karena pertimbangan nilai berita magnitude-nya yang relatif rendah dibanding empat tema lainnya. Selain itu, pemangkasan sub-tema yang dianalisis diharapkan juga dapat mempersempit fokus, dengan demikian membuat pembahasan lebih tajam.

Pemberitaan mengenai urgensi pembuatan Perdais turunan untuk menjadi koridor bagi pelaksanaan program-program yang menggunakan Danais merupakan aspek yang cukup kentara nuansa politisnya. Belum adanya Perdais dianggap menjadi salah satu penyebab begitu rendahnya serapan Danais pada dua periode awal pelaksanaannya. Tanpa rel tersebut, pelaksanaan Danais bahkan dikatakan terkesan sebagai bancakan ${ }^{4}$ uang oleh birokrat Pemda DIY. Rasa politis terlihat dari diagnose cause dan moral judgement pada berita-berita yang membahas mengenai topik ini. Kesalahan lebih banyak ditimpakan pada lambatnya DPRD DIY dalam melakukan pembahasan. Meskipun ada juga dalam skala lebih kecil pemberitaan mengenai saling lempar tanggung jawab antara eksekutif dan legislatif, namun secara umum kealpaan ditujukan bagi kinjera DPRD. Termasuk pada ingar bingar Pileg 2014, yang dianggap mengalihkan perhatian anggota legislatif daerah dari tugasnya semula. Kegiatan kampanye pileg melucuti anggota dewan dari fungsi legislasi yang harus mereka jalankan. Padahal tenggat waktu semakin menipis karena beberapa bulan setelah pileg, praktis keanggotaan DPRD akan berganti dengan konfigurasi hasil Pileg 2014.

Fenomena yang berulangkali terjadi dalam tiga termin Danais periode 2013 dan kembali terulang pada termin pertama 2014 adalah serapan dana yang begitu rendah. Masalah ini selalu berulang, dan memunculkan kekhawatiran setiap menjelang akhir suatu termin bahwa pada termin berikutnya, dana tidak akan bisa dicairkan karena serapan pada termin yang bersangkutan terlalu rendah. Untuk masalah ini, pemberitaan Tribun Jogja mengidentifikasi sejumlah penyebab yaitu tenggat waktu yang terlalu sempit, regulasi dari pemerintah pusat yang kurang kondusif, ketidaksiapan jajaran Pemda DIY,

\footnotetext{
4 Tradisi dalam budaya Jawa untuk berbagi makanan kepada tetangga dan kerabat sebagai ucapan syukur. Dalam hal ini bancakan dimaknai secara negatif, sebagai sindiran terhadap perilaku aktor-aktor dalam pemerintahan yang berbagi aliran dana yang didapat dari anggaran secara ilegal.
} 
Tabel 1.

Framing Tribun Jogja Terhadap Topik Urgensi Perdais dan Rendahnya Serapan Danais

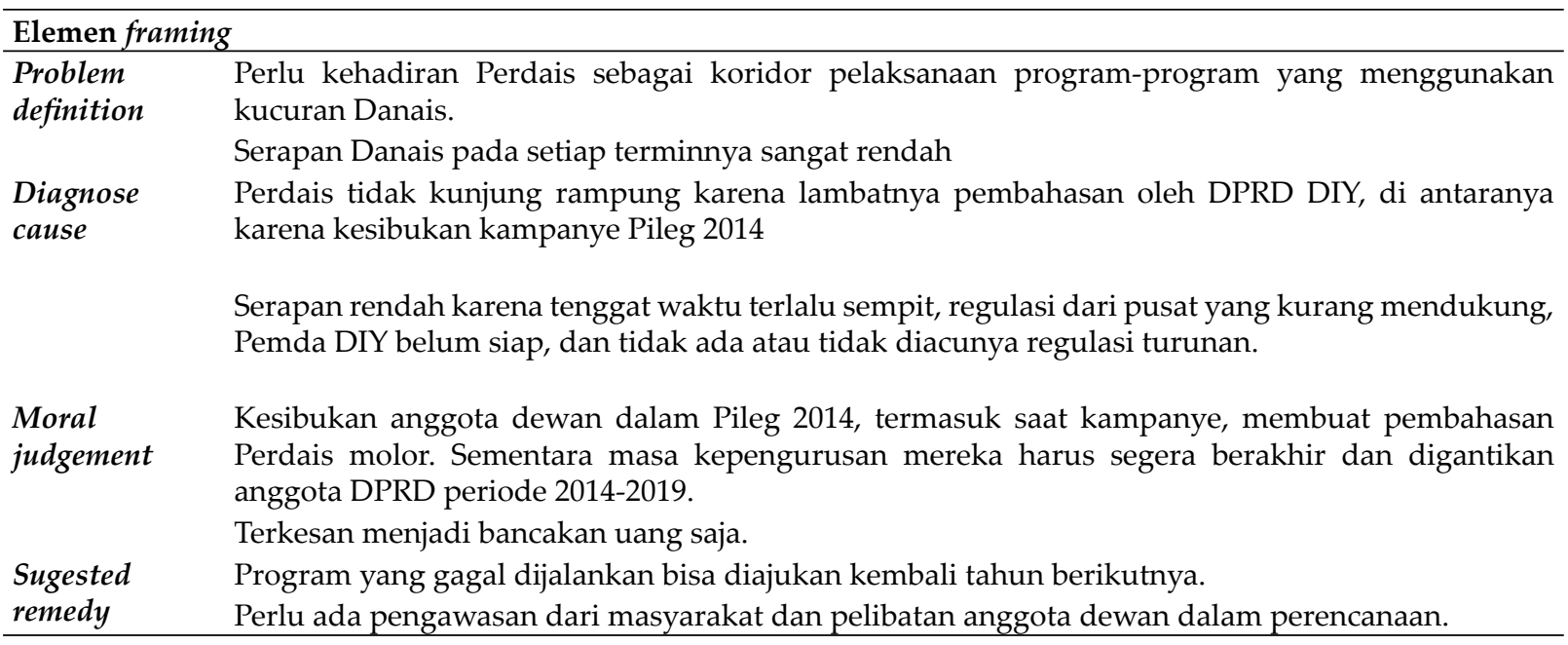

dan belum adanya regulasi yang diacu dalam koordinasi pusat-daerah seperti Rencana Pembangunan Jangka Menengah Daerah (RPJMD), Rencana Kerja Pembangunan Daerah (RKPD), serta Perdais turunan. Adapun solusi yang ditawarkan dalam teks berita yang paling sering ditawarkan yaitu program yang gagal dijalankan periode tahun ini, agar dicoba diajukan lagi tahun berikutnya. Satu jenis solusi lagi adalah adanya pengawasan dari masyarakat dan pelibatan anggota DPRD dalam pelaksanaannya. Namun alternatif terakhir hanya muncul pada satu berita.

Sub-tema selanjutnya adalah ketepatan prioritas dan alokasi Danais. Pemberitaan mengenai perlunya perbaikan rumah bangsawan yang berstatus Benda Cagar Budaya (BCB) menimbulkan kesan adanya keberpihakan pada keluarga Keraton Kesultanan Yogyakarta maupun Pura Pakualaman. Para aristokrat digambarkan telah berusaha memperbaiki kondisi bangunan berumur ratusan tahun, namun tidak bisa berhasil sepenuhnya baik karena faktor besarnya biaya maupun bencana alam seperti gempa bumi 2006 atau hujan abu vulkanik Gunung Kelud 2014.

Sementara mengenai strategi alokasi, tampak ada kesan meletakkan kesalahan pada pemerintah pusat. Upaya serapan Danais di lapangan, sebaik apapun koordinasi dan perencanaannya, akan mandul ketika pusat gagal menunjukkan sikap kooperatif. Misalnya ketepatan dengan jadwal yang telah disepakati dan diumumkan, perihal keleluasaan tenggat waktu yang diberikan, maupun pemahaman mengenai kondisi riil di lapangan. Berkaitan dengan problem rendahnya persentase serapan Danais oleh jajaran Pemda DIY, perubahan strategi alokasi dan prioritas menjadi alternatif yang diajukan. Program yang pelaksanaannya rumit, karena alasan ketersediaan waktu, sementara diabaikan dan diganti dengan program yang lebih sederhana namun juga dapat menyerap dana yang tersedia. Misalnya rencana renovasi rumah $\mathrm{BCB}$ diganti menjadi pembelian rumah $\mathrm{BCB}$ di sejumlah lokasi.

Topik selanjutnya yang juga menarik cukup banyak perhatian adalah polemik honor bagi Sri Sultan HB X. Berbeda dengan gaji yang ia terima sebagai Gubernur DIY, honor bagi raja Keraton Kesultanan Yogyakarta (serta seluruh petinggi Keraton maupun raja dan petinggi Pura Pakualaman) yang bersumber dari Danais didapatkan karena posisinya sebagai pemangku adat dan kebudayaan di Yogyakarta. Besarnya memang tidak seberapa 
Tabel 2.

Framing Tribun Jogja Terhadap Topik Strategi Prioritas dan Alokasi Danais

\begin{tabular}{ll}
\hline Elemen framing \\
\hline $\begin{array}{l}\text { Problem } \\
\text { definition }\end{array}$ & $\begin{array}{l}\text { Sebagian Danais dimanfaatkan untuk memperbaiki rumah bangsawan yang tergolong BCB. } \\
\text { Danais juga dialokasikan untuk berbagai program, seperti penataan kawasan Malioboro, digitalisasi } \\
\text { naskah kuno, dan promosi budaya lewat fashio show. }\end{array}$ \\
$\begin{array}{l}\text { Diagnose } \\
\text { cause }\end{array}$ & $\begin{array}{l}\text { Renovasi BCB memerlukan biaya besar, dan bisa ditutupi dengan adanya kucuran Danais sebagai } \\
\text { upaya pelestarian benda tradisi. }\end{array}$ \\
& $\begin{array}{l}\text { Berbagai kegiatan pelestarian dan promosi budaya juga merupakan cara untuk mengakselerasi serapan } \\
\text { Danais. }\end{array}$ \\
Mudgement & $\begin{array}{l}\text { Alokas Danais untuk renovasi rumah bangsawan yang masuk kategori BCB sudah sesuai dengan } \\
\text { ketentuan }\end{array}$ \\
& $\begin{array}{l}\text { Pemerintah pusat gagal bersikap kooperatif sehingga berpotensi menghambat kinerja jajaran Pemda } \\
\text { untuk menyerap Danais. }\end{array}$ \\
Sugested & $\begin{array}{l}\text { Perubahan strategi prioritas dan alokasi Danais bisa menjadi alternatif solusi untuk meningkatkan } \\
\text { akselerasi pemanfaatan Danais. }\end{array}$ \\
\hline
\end{tabular}

Tabel 3.

Framing Tribun Jogja Terhadap Topik Polemik Honor Sri Sultan HB X dari Danais

Elemen framing

Problem Sri Sultan HB X mendapat jatah honor dari Danais dalam posisinya sebagai raja di Keraton Kesultanan definition Yogyakarta

Surat dari KPK menyatakan ada indikasi pelanggaran (gratifikasi) dalam penerimaan honor tersebut, sehingga Sri Sultan memilih mengembalikan honor yang telah ia terima

Diagnose Posisi Sultan sebagai pemangku adat dan tradisi, serta statusnya sebagai raja membuat dirinya patut cause mendapatkan honor yang memang telah dialokasikan dalam Danais

Jumlah honor tidak besar. Indikasi pelanggaran yang diserukan KPK membuat Sultan mengambil langkah aman mengembalikan honor.

Moral Pemberian honor untuk Sultan dan petinggi kerajaan di Yogyakarta bukan hal baru. Kali ini hanya judgement jumlahnya yang lebih besar.

Pengembalian honor merupakan langkah yang bijak daripada harus tersandung oleh masalah hukum padahal dampak finansial dari honor itu kecil.

Sugested Sejak awal, payung hukum pembagian honor dari Danais belum terlalu jelas. Jadi, langkah yang remedy paling tepat adalah mengembalikannya.

dibandingkan gaji sebagai Gubernur dan Wakil Gubernur DIY. Namun karena tata regulasi yang belum matang, muncul kekhawatiran pemberian dana ini dapat menjerat Sultan dalam sengkarut permasalahan hukum. Semula, pemberian honor dianggap lumrah. Selain pos anggarannya di Danais memang tersedia, pada dasarnya pemberian honor bagi pengurus Keraton maupun Pura Pakualaman bukanlah hal yang baru. Selama ini telah ada subsidi pemerintah untuk honor abdi dalem maupun penghageng (petinggi) di dua kerajaan itu. Namun, setelah muncul jawaban dari Komisi Pemberantasan Korupsi (KPK) atas surat pertanyaan dari Sultan mengenai boleh tidaknya ia menerima honor tersebut, maka arah pemberitaan bergeser pada bagaimana Sultan menanggapi "indikasi adanya pelanggaran" tersebut dengan mengembalikan seluruh honor dari Danais yang telah ia terima.

Sikap Sultan sendiri dalam pemberitaan digambarkan pasrah dan tidak mempermasalahkan apakah nantinya ia bisa menerima honor itu. Besaran honor yang tidak seberapa menjadi pertimbangan yang sempat diangkat, seperti yang disampaikan oleh seorang petinggi Keraton. Power dari penegak hukum bernama KPK dalam isu ini terasa begitu kuat. KPK menjadi pihak kepada siapa Sultan berkonsultasi melalui surat perihal legalitas honor yang bersangkutan. Ketika jawaban sudah didapatkan, betapa 
Tabel 4.

Framing Tribun Jogja Terhadap Topik Program Sosialisasi Pencegahan Malaria Menggunakan Metode Wayang

\begin{tabular}{ll}
\hline Elemen framing \\
\hline $\begin{array}{l}\text { Problem } \\
\text { definition }\end{array}$ & Kegiatan sosialisasi pencegahan Malaria dengan pentas wayang dianggap mengada-ada dan dihubung- \\
Diagnose & Dampungkan dengan aspek budaya agar bisa mendapatkan kucuran Danais. \\
cause & Regulasi turunan yang memayungi atau menjadi koridor belum tersedia. \\
$\begin{array}{l}\text { Moral } \\
\text { judgement }\end{array}$ & Program tersebut dianggap mengada-ada dan hubungannya tidak relevan. \\
$\begin{array}{l}\text { Sugested } \\
\text { remedy }\end{array}$ & $\begin{array}{l}\text { Perlu ada regulasi turunan, misalnya Perdais, yang bisa diacu sebagai koridor penterjemahan aspek } \\
\text { budaya yang interpretasinya masih terlalu luas. }\end{array}$ \\
& $\begin{array}{l}\text { Perlu lebih waspada dalam memanfaatkan dana publik, apalagi mengingat saat itu adalah tahun } \\
\text { politik. }\end{array}$ \\
\hline
\end{tabular}

tidak tegasnya sekalipun, Sultan memilih bersikap aman dengan mengembalikan honor tersebut. Pembingkaian berita untuk topik ini tidak melepaskan sosok Sultan HB X sebagai raja Keraton dan posisinya sebagai Gubernur DIY, karena justru karena peran ganda itulah, polemik upah ini timbul.

Topik terakhir adalah mengenai program sosialisasi pencegahan penyakit malaria di Kabupaten Kulonprogro menggunakan metode wayang dan dibiayai dengan Danais. Program ini mendapat sorotan tajam karena dianggap mengada-ada dan memanfaatkan celah interpretasi kewenangan kebudayaan yang memang belum punya koridor yang jelas, meskipun dalam pemberitaan juga ditampilkan data dari dinas terkait mengenai kasus malaria di Kecamatan Kokap, Kabupaten Kulonprogo, yang memang paling tinggi di DIY. Namun data ini tidak banyak disinggung. Dalam hal ini, absennya regulasi turunan seperti Perdais dan masa transisi itu sendiri dianggap memberi andil bagi munculnya masalah yang diduga merupakan usaha dari pemerintah daerah untuk menyadap kucuran Danais tersebut.

Framing terhadap topik tersebut menegaskan pentingnya kehadiran regulasi turunan yang bisa mendetilkan berbagai aspek dalam UU Keistimewaan sehingga pelaksanaannya tidak melenceng. Selain itu, Tribun Jogja juga mengambil angle tahun politik sebagai faktor yang menyebabkan bentuk- bentuk penyelewengan kucuran dana ratusan miliar rupiah dari pemerintah pusat itu perlu mendapat pengawasan yang lebih ketat.

\section{Kesimpulan}

Pembingkaian isu implementasi Danais oleh Harian Tribun Jogja memperlihatkan kira-kira sejauh mana media massa lokal non partisan tersebut menjalankan fungsinya sebagai salah satu komponen penting dalam demokrasi pada level sub nasional. Serapan anggaran berada di tangan eksekutif. Untuk sampai ke sana, peran legislatif diperlukan guna mendefinisikan rel yang bisa dititi pemerintah. Di antara dua lembaga tersebut, Tribun Jogja cenderung mengarahkan kesalahan pada legislatif. Kinerja DPRD DIY dalam membahas Raperdais turunan, terutama mengenai aspek kebudayaan, dianggap lambat. Padahal, masa kerja DPRD DIY periode 2009-2014 akan berakhir dalam jangka waktu beberapa bulan. Terkait dengan itu, gelaran Pileg 2014 serta masa kampanyenya membuat kinerja anggota dewan melambat. Fungsi legislasi yang seharusnya masih mereka jalankan secara normal terusik akibat kesibukan promosi diri kepada konstituen. Di sudut berlawanan, eksekutif dianggap sudah menempuh cara-cara yang bisa dilakukan dalam segala keterbatasan payung hukum dan sumber daya, untuk menyerap kucuran Danais tanpa melakukan pelanggaran hukum. Langkah pemerintah 
untuk mengubah prioritas mendapat perhatian lebih dibanding kealpaan mereka hingga melahirkan program yang dinilai mengadaada. Halangan bagi Pemda DIY semakin diperkuat dengan sikap pemerintah pusat yang kerap kurang kooperatif dan gagal menciptakan regulasi yang kondusif bagi kinerja rekan mereka di daerah.

Menilik konsep demokrasi Merkel, fungsi pers dalam rezim political right yang menjadi prasyarat bagi tumbuhnya demokrasi yang utuh masih belum berjalan optimal. Mekanisme pengawasan/public watchdog sudah berjalan, berupa paparan terhadap isu implementasi Danais dari waktu ke waktu. Meski demikian, dari segi konten, prinsip reward and punishment terasa masih terlalu lemah. Konsekuensi dari apa yang dilakukan atau tidak dilakukan, baik oleh eksekutif maupun legislatif di daerah, belum dipaparkan secara jelas. Sementara pengawasan dari masyarakat menempati posisi minor dalam alternatif solusi yang ditawarkan. Media massa lokal, atau dalam penelitian ini spesifik pada Harian Tribun Jogja, terjebak pada kerangka pikir bersifat administratif-birokratis. Manuver pemerintahan yang bersifat politis sekalipun hanya bisa diluruskan melalui mekanisme yang terpatri dalam rumusan hukum positif atau hierarki organisasi formal. Misalnya lewat perdais atau koordinasi antar lembaga pemerintahan baik horizontal maupun vertikal. Sementara masyarakat, sebagai kekuatan laten nyata tidak banyak dilibatkan.

Menariknya, mekanisme elektoral dipandang sebagai salah satu hambatan dalam jalannya pemerintahan sehari-hari. Instrumen demokrasi prosedural itu justru menyita perhatian dan memandulkan kinerja anggota dewan dalam mempersiapkan kelancaran tugas rekan mereka di eksekutif. Mekanisme tersebut tidak diajukan sebagai jalur bagi masyarakat untuk memberikan penilaian dan penghakiman bagi kaum berkuasa.

Secara umum, bisa dikatakan bahwa demokrasi pada level sub nasional belum bisa berjalan secara utuh. Prasyarat berupa political right yang bisa disediakan oleh pers, baru bisa dijalankan setengah hati. Distribusi demokrasi melalui prinsip desentralisasi tampak belum terwujud sampai ke akarnya pada level daerah. Sementara kebebasan pers dari represi politik pemerintah tidak serta merta menjamin kebebasan peran pers untuk menyiapkan prasyarat bagi tumbuhnya demokrasi itu sendiri. Bahaya utama masih terletak pada kerangka pikir administratif. Pemikiran tersebut tidak sepenuhnya salah. Bagaimanapun warna desentralisasi di Indonesia memang terasa kuat pada aspek teknokratis, dan begitu lemah pada faktor demokratisasinya. Namun kecenderungan kerangka pikir tersebut, sebagaimana terlihat terjadi pada analisis kasus, cenderung mengesampingkan peran masyarakat secara umum. Meski peran regulasi formal merupakan hal yang penting, faktor kehadiran masyarakat sebagai pengontrol jalannya pemerintahan baik pada lembaga eksekutif maupun legislatif tidak bisa diabaikan begitu saja.

\section{Daftar Pustaka}

Aziz, Abdul dan David D. Arnold. (2003). Desentralisasi Pemerintahan Pengalaman Negara-Negara ASEAN. Bantul: Pondok Edukasi.

Baswedan, Anies. (2007). Prakata. Politik Lokal di Indonesia (Henk Schulte Nordholt dan Gerry van Klinken (ed). Jakarta: Yayasan Obor Indonesia.

Devas, Nick. (2005). The Challenges of Decentralization. Global Forum on Fighting Corruption

Entman, Robert M. (1993). Framing: Toward Clarification of a Fractured Paradigm. Journal of Communication. Vol. 43 No. 4, hlm. 51-58

Eriyanto. (2002). Analisis Framing: Konstruksi, Ideologi, dan Politik Media. Yogyakarta: PT LkiS Pelangi Aksara.

Haryanto. (2009). Elit Politik Lokal dalam Perubahan Sistem Politik. Jurnal Ilmu 
Sosial dan Ilmu Politik. Vol. 13 No. 2 Edisi November.

Kaho, Josef Riwu. (2012). Analisis Hubungan Pemerintah Pusat dan Daerah di Indonesia Edisi Revisi Cetakan Ketiga. Yogyakarta: Centre for Politics and Government Fisipol UGM

Imawan, Riswandha. (2005). Desentralisasi, Demokratisasi, dan Pembentukan Good Governance. Desentralisasi dan Otonomi Daerah. Syamsuddin Harris (ed.) Jakarta: LIPI Press.

Ishwara, Luwi. (2008). Catatan-catatan Jurnalisme Dasar. Jakarta: Kompas.

Kumorotomo, Wahyudi. (2005). Pelaksanaan Otonomi Daerah Provinsi dan Kabupaten/Kota di Yogyakarta. Yogyakarta: Media Wacana.

Lay, Cornelis. (2012). Democratic Transition in Local Indonesia: An Overview of Ten Years Democracy. Jurnal Ilmu Sosial dan Ilmu Politik. Vol. 15 No. 3 Edisi Maret.

Lele, Gabriel. (2012). The Paradox of Distance in Decentralized Indonesia. Jurnal Ilmu Sosial dan Ilmu Politik. Vol. 15 No. 3 Edisi Maret.

Mahatma, Masmuni. (2006). Pembasisan Demokrasi. Membangun Indonesia dari Daerah. M. Djajono, I Made Leo Wiratama, TA Legowo (ed). Jakarta: CSIS.

Maryanov, Gerald S. (2007). Decentralization in Indonesia as A Political Problem. Jakarta, Kuala Lumpur: Equinox Publishing.

Massoi, L. dan Norman, A. S. (2009). Decentralisation by Devolution in Tanzania: Reflections on Community Involvement in The Planning Process in Kizota Ward in Dodoma. Journal of Public Administration and Policy Research.Vol. 1 No. 7

Merkel, Wolfgang. (2004). Embedded and Defective Demoracies. Democratization. Vol.11 No.5

Nordholt, Henk Schulte dan van Klinken, Gerry. (2007). Politik Lokal di Indonesia. Jakarta: Yayasan Obor Indonesia.

Schechter, Danny. (2007). Matinya Media Perjuangan, Menyelematkan Demokrasi. Jakarta: Yayasan Obor Indonesia.
Sharma, Chanchal Kumar. (2004). Decentralization Dillema: Meassuring the Degree and Evaluating the Outcomes. MPRA Paper No. 204, posted 7 October 2006

Siregar, Ashadi. (2011). Democratic Governance dan Hak Asasi Manusia: Makna Kebebasan Pers dalam Otonomi Daerah. Jurnal Ilmu Sosial dan Ilmu Politik. Vol. 14 No. 3 Edisi Maret.

Sugiharta, Sri. (2012). Desentralisasi dan Sumber Daya Aparatur: Problematika Pelaksanaan Desentralisasi Pelestarian Cagar Budaya di Provinsi Sumatera Barat, Riau, dan Kepulauan Riau. Jurnal Ilmu Sosial dan Ilmu Politik. Vol. 15 No. 3 Edisi Maret.

Sutrisno, Petrus Suryadi. (2011). Fenomena Kebangkitan Industri Pers Daerah / Media Lokal. Jurnal Dewan Pers. No. 5 Edisi Mei.

Tsai, Lily L. (2007). Accountability Without Democracy, Solidary Groups and Public Good Provision in Rural China. New York: Cambridge University Press

Yusuf, Iwan Awaluddin. (2011). Media Lokal dan Konstelasi Komunikasi Politik di Daerah. Jurnal Ilmu Sosial dan Ilmu Politik. Vol. 14 No. 3 Edisi Maret.

\section{Berita dari Media Online}

Tribun Jogja. (2014). Bidang Kebudayaan Dapat Alokasi Rp 375,1 Miliar Danais 2014. (Online). (http://jogja.tribunnews.com/2014/01/16/ bidang-kebudayaan-dapat-alokasi-rp-3751miliar-danais-2014/, diakses 23 Oktober 2014)

Tempo.co. (2013). Permintaan Dana Keistimewaan Dinilai Tak Wajar. (Online). (http://www. tempo.co/read/news/2013/02/01/058458537/ Permintaan-Dana-Keistimewaan-DinilaiTak-Wajar, diakses 23 Oktober 2014)

Berita dari Surat Kabar

Tribun Jogja, 13 Desember 2013. Danais Bisa Jadi Bumerang: IDEA Sebut Pemda DIY Belum Siap Kelola Danais.

Tribun Jogja, 1 Mei 2014. Djoko Siap Kawal Keistimewaan: Cegah Danais untuk Kelompok Gadungan. 